\title{
Ethics, practically speaking
}

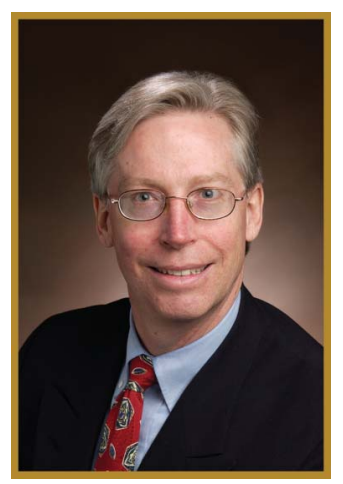

A

s practicing neurologists, we are faced continually with a diversity of ethical challenges. This issue of Neurology ${ }^{\circledR}$ Clinical Practice features several articles approaching various aspects of medical ethics including prescribing medication, relationships with Pharma, effects of social programs, and legal ethics.

Pylkas and Bart discuss the perils of prescribing controlled substances in the midst of a drug epidemic and offer risk management strategies. Mateen et al. present a retrospective observational study that concludes that adults insured by Medicaid are more likely to present as inpatients and with life-threatening neurologic disease compared to privately insured patients. The authors contend that the relationship of their findings to educational status, household income, comorbidities, and the reasons prompting Medicaid eligibility require additional study. H. Richard Beresford discusses dilemmas surrounding care of an undocumented immigrant and puts them into legal context.

In our Current Controversies section, we present a provocative debate on the relationships between physicians and Pharma. Carl Elliot argues that all interactions of physicians with Pharma that directly or indirectly involve money are inherently complicated by conflicts of interest (COIs), which by their nature have a negative effect on the patients we serve. While the Editors share many of the concerns raised by Dr. Elliot, we think it appropriate to have a dialogue with our readers about the nature of the potential conflicts, and the ways COIs can or cannot be mitigated or averted. In that vein, without commenting further as to our personal beliefs, we offer arguments supporting positive and necessary collaborations between physicians and Pharma for which potential COIs must be successfully managed. Please get involved in the discussion.

We welcome your feedback on these articles and seek your own practical, real-world advice on how you confront and navigate ethical pitfalls in your practice. We will publish a selection of advice in an upcoming edition of The Nerve!
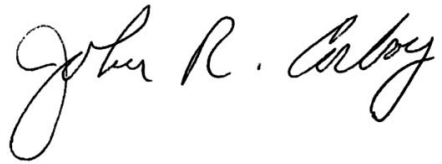

John R. Corboy, MD, FAAN 


\section{Neurology ${ }^{\circ}$ Clinical Practice}

Ethics, practically speaking

Neurol Clin Pract 2014;4;93

DOI 10.1212/CPJ.0000000000000018

This information is current as of April 14, 2014

Updated Information \& Services

Permissions \& Licensing

Reprints including high resolution figures, can be found at:

http://cp.neurology.org/content/4/2/93.full.html

Information about reproducing this article in parts (figures,tables) or in its entirety can be found online at:

http://cp.neurology.org/misc/about.xhtml\#permissions

Information about ordering reprints can be found online: http://cp.neurology.org/misc/addir.xhtml\#reprintsus

Neurol Clin Pract is an official journal of the American Academy of Neurology. Published continuously since 2011, it is now a bimonthly with 6 issues per year. Copyright (C) 2014 American Academy of Neurology. All rights reserved. Print ISSN: 2163-0402. Online ISSN: 2163-0933.

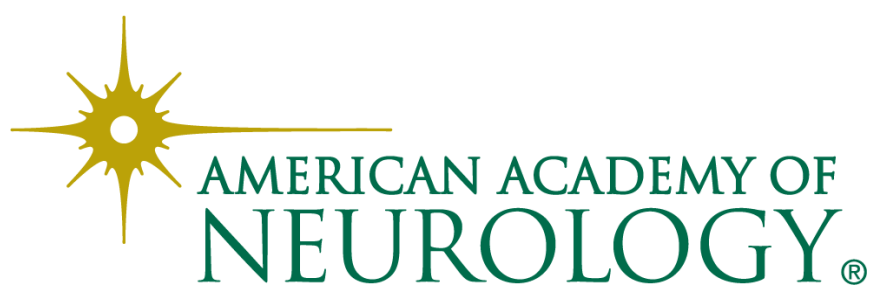

